\title{
Nutritional management to improve sheep and goat performances in semiarid regions
}

\author{
Hichem Ben Salem ${ }^{1}$ \\ ${ }^{1}$ Institut National de la Recherche Agronomique de Tunisie (INRAT), Laboratoire des Productions Animales et Fourragères, Rue Hédi Karray, \\ 2049 Ariana, Tunisia.
}

ABSTRACT - Small ruminant production is the main source of income of farmers living in arid and semiarid regions. Sheep and goats raised in these areas are generally confronted with severe nutritional deficits during food scarcity period which exacerbate disease and health problems and consequently low productive and reproductive performances. These areas are characterized by rainfall seasonality and scarcity resulting in a low fodder potential. Therefore, native rangelands are degrading due to overgrazing, high stocking rates and mismanagement. Options to improve small ruminant-based production systems include i) innovative technologies targeting the increase of feed resources availability, rumen manipulation using natural compounds to boost microbial activity, improving diets' quality, alleviation of feeding cost, and better control of livestock watering. Although this paper is focussing on the benefits from these technical options, we should bear in mind that $i$ ) the organization of local institutions for better adoption of these technologies and for protecting the main natural resources (rangelands and water) and ii) the participatory approach involving all partners concerned with the improvement of farmer's income and livelihood are key tools for promoting livestock sector in the target areas. A set of simple, inexpensive and environmentally friendly options that could ameliorate small ruminant production in the semiarid regions are discussed in this paper.

Key Words: alternative feeds, feeding management, performance, semiarid regions, small ruminants

\section{Manejo nutricional para melhorar o desempenho de ovinos e caprinos em regiões semiáridas}

RESUMO - A produção de pequenos ruminantes é a principal fonte de renda dos agricultores que vivem em regiões áridas e semiáridas. Ovinos e caprinos criados nessas áreas geralmente enfrentam severas deficiências nutricionais durante o período de escassez de alimentos, que comprometem a sua saúde e, conseqüentemente, resultam em baixo desempenho produtivo e reprodutivo. Estas áreas são caracterizadas pela sazonalidade e escassez das chuvas, que resultam em baixo potencial forrageiro. Além disso, as pastagens nativas são degradadas devido ao super pastejo, às altas taxas de lotação e ao manejo inadequado. As opções para melhoria dos pequenos sistemas de produção de ruminantes incluem: o uso de tecnologias inovadoras visando o aumento da disponibilidade dos recursos alimentares, manipulação ruminal utilizando compostos naturais para incrementar a atividade microbiana, redução dos custos com alimentação e melhor controle da irrigação na pecuária. Embora este trabalho enfoque os benefícios dessas opções técnicas, também focaremos: i) a organização das instituições locais para melhor adoção dessas tecnologias e para proteger os principais recursos naturais (pastos e água); e ii) a abordagem participativa incluindo todos os parceiros envolvidos com a melhoria do rendimento dos agricultores de subsistência, que são instrumentos fundamentais para o incremento da pecuária nas áreas em questão. Um conjunto de opções simples, baratas e ambientalmente corretas que poderiam melhorar a produção de pequenos ruminantes nas regiões do semiárido serão discutidas neste artigo.

Palavras-chave: alimentos alternativos, desempenho, manejo alimentar, pequenos ruminantes, regiões semiáridas

\section{Introduction}

Livestock, mainly sheep and goats, rearing is the mainstay of the land and most of the rural population depends on livestock and their by-products (Ben Salem \& Smith, 2008). Agricultural farming in semiarid and arid regions is practiced on a limited scale due to scanty and uncertain rains and shortage of irrigation water leaving most of these regions to be used as rangeland grazing. Due to the increasing rate of rangeland degradation and economic instability at the international level, livestock feeding is facing serious difficulties related to quantitative and qualitative provision of nutrients and this is exacerbated by the continuous increase of feedstuffs' prices. Climate 
change leading to frequent and extended drought periods, is complicating the situation. Sheep and goats raised under these conditions are generally grazing on degraded rangelands and or offered low quality fibrous feedstuffs like cereal straws and stubbles. Nutrient contents of these feed resources are so low and unbalanced that the provision of complements is necessary for livestock maintenance and production. Concentrate feeds (e.g. barley, maize, soybean meal, etc.) are commonly used to tackle this objective. However, the impact of such supplementation strategy on livestock performances is often unsatisfactory and too expensive for smallholders. A wide range of alternative feed sources (e.g. fodder shrubs, some agro-industrial byproducts, etc.) and some natural compounds (e.g. tannins and saponins) proved efficient in improving sheep and goat performances and or reducing feeding cost. Benefits from these alternative feed resources, mainly their impact on digestion and productive performances of sheep and goats are discussed in this paper.

\section{Main constraints of small ruminant sector}

Small ruminants are prevailing in local livestock systems. In crop-livestock-rangeland rainfed mixed systems, livestock substitutes for natural and purchased inputs, in addition to producing meat and milk. The ranges in their present form do not produce year-long forage requirements and almost all vegetation goes dormant during winter season. The livestock, mostly small ruminants, depend on the diet provided for a small part now by rangelands, and mostly by complements, crop residues (cereals, vegetables, etc.) and some forages. The low current contribution of rangelands to livestock feeding is due to the tremendous increase in sheep and goat numbers, but also to the loss of traditional management tools and the modification of land tenure occupation. The vegetation in general and particularly the tree flora have been extremely misused and the rangelands degraded by man and his livestock. The overgrazing of the rangelands has been historic but what amounts to destruction in many parts is recent, following mechanised transport and feed subsidy to pastoralists. Sheep and goats are collecting nearly all available annuals and ephemeroids on the range. They are heavily dependent on hand-fed concentrates, agro-industrial by-products, cereals and straws. Diets containing these feed resources are often unbalanced for main nutrients, thus can not overcome microflora and host animal requirements. While chemicalbased promoters (e.g. antibiotics, probiotics, etc.) proved efficient in stimulating rumen digestion and consequently in increasing sheep and goat performances, the recent concern of consumers about the risk on consuming meat and milk of animals receiving these additives encouraged scientists to look for simple, cost-effective and healthy alternatives. The advantageous use of alternative feed resources in sheep and goat feeding is discussed in the forthcoming sections.

Promising solutions to ameliorate small ruminant sector

Lack of adequate year-round feed resources is probably the most important factor contributing to low animal production in arid and semiarid regions in the world (Ben Salem \& Smith, 2008; Kawas et al., 2010). The recent leap in prices of concentrate feeds and the continuous increase of the price of petroleum at the international level is making machinery-based agriculture in serious difficulty and threatening livestock sector. Therefore, there is an urgent need to develop appropriate strategies for better use of local feed resources and to identify technologies optimizing the potential use of these unconventional feedstuffs in livestock feeding. Expected benefits from these strategies and technologies are discussed in the forthcoming sections.

\section{Adapted forages}

Forage production in the semiarid regions is low. Often forage species and cultivars adapted to humid conditions are cultivated in these regions, thus they are exposed to heat and water stresses. Important quantities of dried forages moved from humid zones towards dry areas in the form of baled hay and or straw for livestock feeding. Extension of appropriate species and cultivars of various forages and legumes for specific agroclimatic and field situations is required to enhance livestock sector. More research is needed on the screening of species and cultivars, agronomy, nutritional evaluation, utilization, and large-scale propagation under commercial conditions. These efforts are the joint responsibility of crop and animal scientists. Because fertile land and water are limiting factors of fodder production in the semiarid regions, the strategy for increasing fodder production should explore the inclusion of selected forages and legumes into prevailing cropping pattern in the context of more intensive systems and land use. Although some improved cultivars adapted to dry conditions have been developed by breeders, most of them are not widely cultivated. North African farmers are more familiar with cereals than forage species. Therefore, the establishment of the forage (legumes) - cereals rotation is difficult and the understanding of forage legumes systems is complicated for farmers. This system requires good knowledge of the technical itinerary and of the physiology of forage species. Additionally, rotation between annual species and the rotation between perennial forage species, e.g. LucerneMedics-graminae is overpowered by farmers. 
Better use of agroindustrial byproducts - Agroindustrial by-products (AGIBPs) refer to the by-products (e.g. olive cakes, molasses, tomato pulp, fruit pulps such as grape marc and citrus pulp) derived in the industry due to processing of the main products. They are, in comparison to crop residues, less fibrous and more concentrated, and often have a high nutrient content. Recycling, reprocessing and utilization of any AGIBPs offer the possibility of alleviating the current limited feed resources and to reduce feeding cost.

Little is known about the deleterious effects, in animals, of feeding AGIBPs. For example, condensed tannins are abundant in grape marc, which explain its low nutritive value. Although, high quantities of some AGIBPs are produced in many countries the utilisation of these feed resources in livestock feeding is still limited. This situation is likely due to proximity of the AGIBP to livestock flock (transportation and storage needs), alternative uses and the relative opportunity costs, the nutritive value of the new feed, and the managerial capabilities of the farmer. Some technologies have been developed to overcome this situation, thus to enhance the utilisation of these unconventional feed resources in ruminant feeding.

AGIBPs ensiling - For those farmers having transportation facilities and their flocks are raised in proximity of a specific food industry manufactory (e.g. olive oil extraction, fruit juice extraction, etc.) appropriate ensiling is a promising technique for better use of AGIBPs in livestock feeding. Ensiled citrus pulp, tomato pulp and olive cake are incorporated in the diet of sheep and dairy cattle in some Mediterranean farms.
Feed blocks (FBs) - Feed blocks manufactured by the cold process are made from a mixture of one or more AGIBP (e.g. olive cake, tomato pulp, etc.), binder (e.g. quicklime, cement and clay), water and common salt, as well as urea with or without molasses. They should be airdried until hardness and compactness criteria are met, and then offered to stall-fed or grazing ruminants on low quality diets. The technique of FB making is well described in the literature (Ben Salem \& Nefzaoui, 2003). Some variations in the blocks have been the incorporation of polyethylene glycol as a tannin-inactivating agent, which has increased the utilization of tanniniferous browse foliage in ruminant feeding (Ben Salem et al., 2000). Medicated blocks containing anthelmintic agents and tannins to control internal parasites have been used in Australia and Ethiopia. Mineral enriched FBs (e.g. phosphorus, copper, etc.) were distributed to animals to mitigate their deficiency and improve reproduction in ruminants. Benefits from the integration of FBs in the diet of sheep and goats are reflected by data compiled in Table 1. It is clear that depending on the formula, FBs can replace partially or totally concentrate feeds, thus alleviates feeding costs without detrimental effects on livestock performances. These advantages may explain the increasing adoption of FB technology by farmers in about 60 countries (Ben Salem \& Nefzaoui, 2003; Makkar, 2007).

AGIBPs-based pellets - Conserving AGIBPs in the form pellets is another promising option. Nefzaoui and Ben Salem (unpublished data) have developed and determined the nutritive value of olive cake based pellets. The formula was inspired from ingredient composition of

Table 1 - Compiled data on the potential use of feed blocks (FB) as alternative feeds supplements for sheep and goats (Ben Salem et al., 2005a)

\begin{tabular}{|c|c|c|c|c|c|}
\hline Basal diet & Supplement & Animals & Growth rate (g/day) & Feeding cost variation & Country \\
\hline Stubble grazing & Concentrate $(250 \mathrm{~g} / \mathrm{d})$ & Lambs & 95 & & Algeria \\
\hline Stubble grazing & Conc. $(150 \mathrm{~g} / \mathrm{d})+\mathrm{FB} 1$ & Lambs & 136 & $-81 \%$ & Algeria \\
\hline Wheat straw ad lib & Conc. $(125 \mathrm{~g} / \mathrm{d})+\mathrm{FB} 2$ & Lambs & 66 & $-11 \%$ & Tunisia \\
\hline Straw (310 g/d) & Conc. $(800 \mathrm{~g} / \mathrm{d})$ & Lambs & 120 & & Lebanon \\
\hline Straw (310 g/d) & Conc. $(300 \mathrm{~g} / \mathrm{d})+$ FB3 & Lambs & 110 & $-5 \%$ & Lebanon \\
\hline Fresh Acacia leaves & FB4 & Lambs & 14 & & Tunisia \\
\hline Fresh Acacia leaves & FB5 enriched with PEG & Lambs & 61 & & Tunisia \\
\hline Rangeland grazing & Conc. (300 g/d) & Kids & 25 & & Tunisia \\
\hline Rangeland grazing & FB4 & Kids & 40 & & Tunisia \\
\hline
\end{tabular}

FB1: Wheat bran (10\%), olive cake (40\%), poultry litter (25\%), bentonite (20\%), salt (5\%).

FB2: Wheat bran (25\%), wheat flour (15\%), olive cake (30\%), rapeseed meal (10\%), urea (4\%), quicklime (8\%), salt (5\%), minerals (1\%).

FB3: Wheat bran (28\%), ground barley (10\%), Molasses (44\%), Sesames hull (5\%), White cement (5\%), Minerals (3\%), urea (5\%).

FB4: Wheat bran (28\%), olive cake (38\%), wheat flour (11\%), quicklime (12\%), salt (5\%), minerals (1\%), urea (5\%).

FB5: Wheat bran (23\%), olive cake (31.2\%), wheat flour (9\%), quicklime (9.9\%), salt (4.1\%), minerals (0.8\%), urea (4.1\%), PEG (18\%). 
FB. These pellets were composed of olive cake, wheat bran, rapeseed meal, wheat flour residue, salt and minerals. Urea was removed to avoid any risk of intoxication with excessive ammonia in the rumen. Indeed, while FBs are set aside for supplementing the basal diet and their hardness and compactness oblige the animal to consume small amounts, pellets due to their smaller size will be consumed in higher amounts. The ad libitum intake of these pellets by sheep averaged $2.5 \mathrm{~kg} /$ day. The cost of these pellets was about half of the price of lucerne pellets which are imported and subsidised. In contrast to FBs, mechanisation is necessary to make pellets. In any case, AGIBPs-based pellets seem an interesting technology to reduce the use of conventional feed resources and to satisfy feed demands by farmers. Formulation should continue and evaluation of these pellets on different animal species should be encouraged, then popularizing this technology should be scheduled.

Fodder shrubs and trees (FST) in the smallholders farming systems - The use of shrubs and trees as animal feeds probably goes back as far as when animals were domesticated. Trees and shrubs are part of the environment of many countries. Some species are high in essential nutrients but low in anti-nutritive factors (e.g. Morus $a l b a$ ), some others are low in nutrients but high in secondary compounds (e.g. Pistacia lentiscus) while some shrubs are high in both nutrients and secondary compounds (e.g. Acacia cyanophylla, Atriplex spp.). This is an ecological factor adapted to withstand grazing and to provide ground for selective grazing. In arid and semi-arid rangelands where forage species available are of poor quality, FST could be used as feed supplements to increase animal intake of native resources. They can be used also to defer grazing after the autumn/winter opening rains, so that more production could be obtained. With proper treatment and management, FST could constitute a greater proportion of livestock diets, but good knowledge of their nutritive value and the responses of sheep and goats to nutrients and anti-nutrients factors present in the edible biomass of these FST is requested to ensure their better use in livestock feeding.

\section{(a) Advantageous use of fodder shrubs and trees}

There are many advantages of promoting fodder shrubs and trees, because of their wider adaptability to harsh agro-climatic conditions and ability to produce for a longer period. As trees require little care after the establishment, the cost of production will be low. (a1) Cactus, a promising shrub species - The popularity of cactus (Opuntia spp.) as a feed in numerous dry areas (North Africa, Ethiopia, Northern Brazil, etc.) is increasing. Characterised by a remarkable tolerance to drought conditions, high water use efficiency, a rapid dissemination and growth, a high biomass yield and a multipurpose use, cactus is a promising range species that can promote livestock sector in dry areas and improve farmers' income. Cactus cladodes are high in soluble carbohydrates, calcium and â-carotene (Ben Salem and Abidi, 2009), but they are low in fibre and CP (Stintzing et al., 2005). Therefore, the association of fibre and protein sources to cactus is recommended. The following approaches have been tested for increasing nitrogen content of cactus cladodes:

- Gonzalez (1989) noted that CP content of fertilized cactus was almost double of the not fertilised one (99 vs $55 \mathrm{~g} / \mathrm{kg}$ DM). However, this option of fertilizing the cactus fields has not been accepted by farmers in many countries especially when cactus is cultivated for forage rather than fruit production. Farmers would prefer to use manure or fertilisers for fruit trees and or vegetable crops.

- Breeding is another way to select nitrogen rich clones of cactus. Some selected clones of cactus (i.e. clone TAMUK accession 1270) contained higher than normal CP contents of $110 \mathrm{~g} / \mathrm{kg}$ DM (Felker \& Inglese, 2003).

- Solid state fermentation seems a promising microbial process to produce protein from cactus. The microorganisms (Algae, bacteria, fungi and yeasts) are considered a source of cell protein. They grow rapidly and could be cultivated on diverse substrates like cactus, rendering them rich in protein. The fermentation of cactus with Aspergillus niger resulted in an increase of the crude protein content by $12.8 \%$ (Oliveira, 2001). Araújo et al. (2005) reported a remarkable increase (up to $400 \%$ ) of the proportion of protein ( $260 \mathrm{~g} / \mathrm{kg} \mathrm{DM})$ in cactus cladodes fermented with yeast (Saccharomyces cervisiae). This procedure of protein enrichment of cactus is technically interesting, but its economical benefit should be evaluated before diffusion at the farm level.

Replacing concentrate feeds (i.e. barley) with cactus cladodes had no effect on digestion, lamb growth (Ben Salem \& Abidi, 2009) and performances of late pregnant-early suckling ewes (Rekik et al., 2010) provided that energy from concentrate feeds is replaced by equivalent energy from cactus cladodes. Total replacement of corn and barley with cactus could be achieved without 
any negative effects. However, with forages such as hay, straw and silage the replacement level should not exceed $50 \%$; otherwise digestion, daily gain and milk production is impaired (Ben Salem \& Abidi, 2009).

Cactus could be used in sheep and goat feeding as fresh, dried or ensiled material:

- Cactus cladodes are fed mostly as fresh to cows, sheep, goats and dromedaries. In order to avoid material loss, it is recommended to cut cladodes into small slices (using knives or electric choppers) before offering to animals. Tegegne et al. (2005) concluded that compared to control diet (without cactus) sheep performed better when part of grass hay was replaced by fresh cactus. Total replacement of barley (300 g) by fresh cactus (ca. $3.5 \mathrm{~kg}$ ) had no effect on hay intake, in vivo organic matter digestibility and nitrogen balance in male lambs and kids (Abidi et al., 2009).

- Cactus cladodes could be dried then ground, and the meal obtained used as a supplement feed for animals. Veras et al. (2002) reported that lambs on elephant grass hay supplemented with corn or cactus meal exhibited similar organic matter (OM) intakes and OM and neutral detergent fibre (NDF) digestibilities. Although data on the replacement value of cactus meal for common feedstuffs (e.g. concentrate feeds) are limited, the benefit to cost ratio of this alternative strategy should be studied before diffusion to farmers.

- Cactus ensiling has been evaluated at the laboratory level and to our knowledge this technique is still not adopted at the farm level. Çürek \& Özen (2004) evaluated the nutritive value of cactus cladodes which were chopped (1-2 cm), wilted (DM content 35\%) and then ensiled. Based on $\mathrm{pH}$ and organic acids contents, the quality of this silage was found acceptable. However, its nutritive value was low. It might be advantageous to ensile cactus mixed with other ingredients. Abidi et al. (unpublished data) ensiled fresh cactus cladodes with olive cake and wheat bran. Replacing oaten hay with this silage had no effect on digestible nutrient intakes but decreased the average daily gain of concentrate supplemented lambs from 50 to $37 \mathrm{~g}$. Cactus ensiling seems a simple technique, but its adoption would depend largely on the benefit to cost ratio, amongst others including the technology transfer efforts.

In addition to feed shortage, water scarcity compromises livestock performances in dry areas. Because of its succulence, cactus could overcome this constraint. Indeed, ruminants do not need to drink water when receiving cactus cladodes ( $c a .35$ g dry matter $/ \mathrm{kg}$ metabolic weight) (Ben Salem \& Abidi, 2009). (a2) Benefits from secondary compounds containing shrubs - Plant defensive compounds commonly but loosely addressed as plant secondary compounds include those in categories such as phenolics, saponins, alkaloids, nonprotein amino-acids, essential oils and glycosides. Tannins and saponins are the most widely occurring components from these groups. These two compounds have both beneficial and adverse effects depending upon the nature and the amount an animal consumes (Makkar, 2003). In various studies, foliage as well as fruits and seeds of fodder shrubs and trees have been reported to suppress ruminal protozoa population (Leng et al., 1992; Jouany et al., 2007). This natural defaunating, i.e. protozoa eliminating, activity of some multi purpose trees and shrubs-derived feeds was shown to be the result of their plant secondary metabolites. Reducing methane production can be of direct economic benefit because it coincides with greater energy use efficiency of the feed by the animal. Feed additives (chemicals, organic acids, probiotics) were used in some Mediterranean countries to reduce methane. But, because their use had been banned by the EC, other alternatives are used such as inclusion of oils in diets, feeding diets rich in unsaturated fatty acids, and modifying feeding practices and supplementing roughage-based diets with deficient nutrients. Dietary manipulations result in methane reduction by decreasing fermentation of organic matter in the rumen and shifting the site of digestion from the rumen to the intestines, diverting hydrogen away from $\mathrm{CH} 4$ production during ruminal fermentation, inhibiting methanogenesis by ruminal bacteria or by optimizing the rumen fermentation and thereby decreasing methane emission per unit of organic matter digested.

Tannins - The term «tannin» refers to «tanning» or preservation of skins to create leather, and tannins also contribute to the astringency of many popular drinks, for example tea and wine. These secondary compounds are classified into two categories:

- Hydrolysable tannins HT are potentially toxic and decrease the nutritive value of feedstuffs, thus have in general negative effects on livestock performance. We are not aware of any studies reporting positive effects of HT on animal production.

- Condensed tannins (CT), also known as proanthocyanidins, are widespread in dicotyledonous species and occur infrequently in graminacae. They are present mainly in the foliage of a wide range of shrubs and trees. These secondary plant metabolites were identified in the foliage of some herbaceous species like Sulla 
(Hedysarum coronarium) and sainfoin (Onobrychis viciifolia). CT bind to proteins in the rumen, reduce protein degradation and when dietary crude protein (CP) concentrations exceed animal requirements for $\mathrm{CP}$, these effects can improve performance. However, when dietary $\mathrm{CP}$ concentrations are low and fibre concentrations are high, CT are nearly always detrimental.

In contrast to HT, numerous studies have been carried out to identify and determine the bioactivity and the effects of CT (purified or CT-containing plants) on digestion, productive and reproductive performances and product quality in sheep and goats fed on CT-containing diets. It is clear that depending mainly on their origin, their level, their structure, diet ingredients, animal species and physiological stage, CT could have negative effects but could also under specific conditions provide benefits for ruminant performances. Positive effects of tannins on ruminant digestion and performances were well reviewed in the literature (see for example reviews by Min et al., 2003; Makkar et al., 2007; Waghorn, 2008).

CT to promote protein value of diets. Although tannins are generally viewed as antinutritional, certain types/kinds of tannins at low concentrations are known to alter rumen fermentation of carbohydrates and proteins and microbial protein synthesis to the benefit of ruminants. Since tannins are widely distributed in plants, identification of tanniniferous feedstuffs having beneficial effects on ruminant digestion would provide useful hints to exploit the use of such feedstuffs to improve efficiency of ruminant digestion. Some illustrations on the positive effect of tannins on sheep growth are reported in Table 2. These findings were ascribed to decreased ammonia concentration and protein degradation in the rumen due to tannins binding.

CT to control gastrointestinal parasites (GIP) in ruminants. The presence of GIP disturbs mainly protein metabolism. Such effect may explain the decreased growth of ruminants harbouring high parasites load. Treatment against GIP is necessary to improve livestock performances and health. Commercial anthelmintics are used mainly in the organised sector but seldom by smallholders, particularly in developing countries. Indeed these veterinary drugs are expensive and an alarming calls by specialists for the development of anthelmintics resistance in worm populations, particularly in sheep and goats. The development of alternative solutions is nowadays a research priority in the world. This priority coincides with the public concern for more sustainable production systems, relying less on the use of chemicals to improve feeding efficiency and to improve livestock health. Nutritional manipulation of the host animal in order to improve the host resistance and/ or resilience to parasitic infections seems a promising option. Recent studies showed that the incorporation of CT-containing feedstuffs in the diet reduced GIP. But, the rate of such decrease varied among these studies probably because different CT sources, CT levels, diet composition and animals were used. According to Hoste (2005), tannins might interfere directly with the biology of various nematode stages and they could indirectly improve the host nutrition by protecting the diet proteins from ruminal degradations and this could modulate worm biology. Recent studies in some laboratory showed that repeated distribution of sainfoin hay (Hoste et al., 2006), Acacia cyanophylla foliage (Akkari et al., 2008) reduced faecal egg counts in kids and lambs, respectively.

Saponins are glycosides of aglycone linked to one or more sugar chains. The biological effects of these compounds include defaunation and increased nutrient absorption rates. This property is associated with a decrease of lower level of ammonia in the rumen fermentation system and an improvement of the efficiency of microbial synthesis. Saponins are also known to increase permeability of the intestinal mucosal cells. This probably led to better absorption of nutrients from the intestine. The possible use of natural plant products as a growth promoter provides cheaper, safer and more consumer acceptable alternatives to synthetic compounds. Inclusion of saponin-containing plants or their extracts in the diets of ruminants has received wide interest. However, their use in practice is still limited.

Overall the interesting results about the advantageous use of tanniniferous and/or saponin containing forages to improve feed efficiency and to control GIP, thus to improve productive and reproductive performances of ruminants should encourage the establishment of practical options for agronomical applications of plants containing these natural secondary compounds in grazing systems. Table 2 reports some findings on the effects of saponin or tannin supply on feed intake, diet digestibility, fermentation parameters and growth of sheep and goats.

(a3) Alley-cropping technique - It consists of cultivating herbaceous vegetation (graminae and or legumes) between rows of tree or shrub species. In the intercropping system, shrubs are grown along with cash 


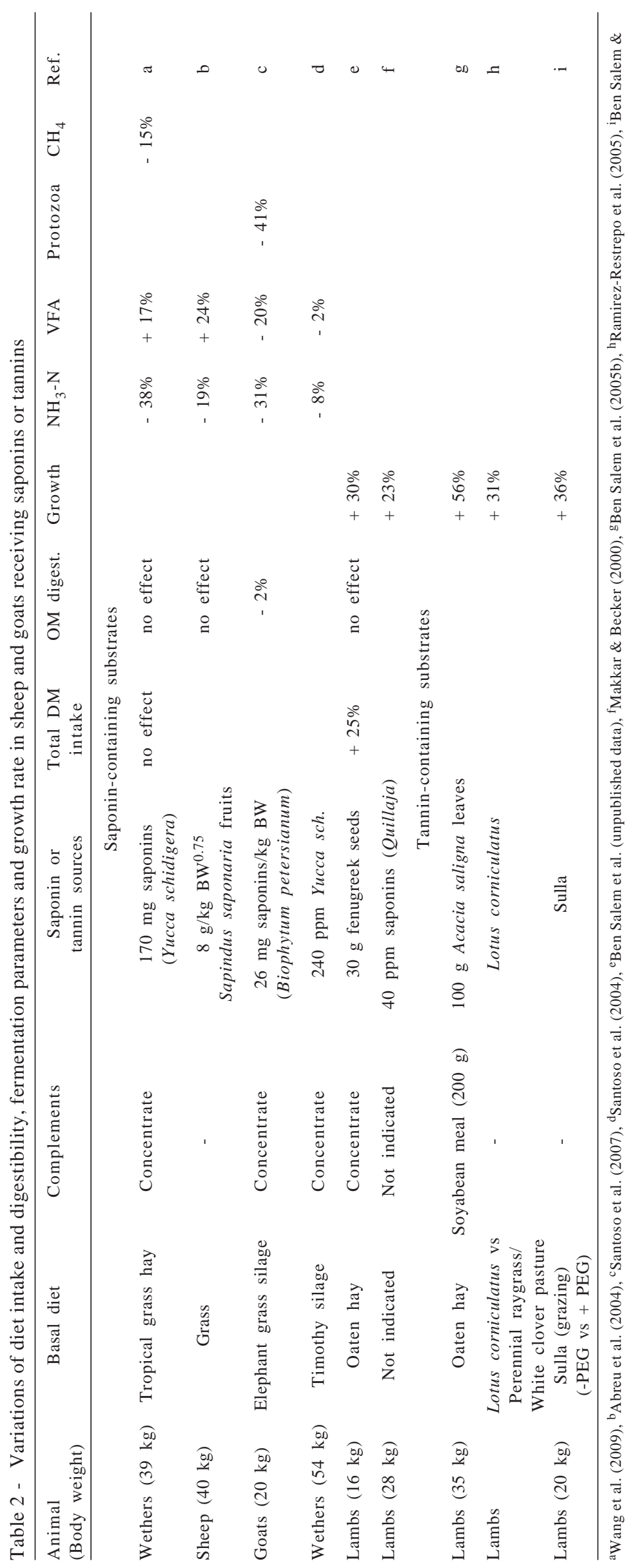


crops in the form of wind rows (Acacia cyanophylla or Atriplex nummularia in timber crops like barley), between cash crop plants, with the cash crop plant or scattered among the cash crop plants. The shrubs and trees should be lopped periodically to prevent overshading the cash crops. One of the reasons of the failure of the adoption of fodder shrubs and trees plantation in Mediterranean countries is the high density of the plantation imposed by development organisms in private farms mainly in the semiarid zones where cereals cropping is dominating, although yields are often low due to low and irregular rainfall and poor agronomic practice. Other crops, including forage grasses and shrubs are often restricted although intercropping of cereals and shrubs has been adopted by some farmers. Established trees and shrubs, usually leguminous so that the soil benefits from both mulch and nitrogen fixation are cut back when the cereal crop is planted and then periodically pruned during the growing season to prevent shading and reduce competition with the associated food crops. After harvest the woody species are allowed to grow freely to produce foliage for sheep and goat feeding. This system (i) improves soil; (ii) increases crop yield; (iii) reduces weeds, and (iv) improves animal performance. Properly managed, alley-cropping allows diversification to benefit from several markets. It also promotes sustainability in both crop and livestock production. The benefits from cactus-barley cropping system have been evaluated in Tunisia (Alary et al., 2006). Compared to barley alone, the total biomass (straw plus grain) of barley cultivated between the rows of spineless cactus increased from 4.24 to 6.65 tons/ha and the grain yield from 0.82 to 2.32 tons/ha. These results are due to the change of the microenvironment created by alley-cropping with cactus, which creates a beneficial "wind break" role reducing water loss and increasing soil moisture. The barley crop stimulated an increase in the number of cactus cladodes and fruits, while the cactus increased the amount of root material contributing to the soil organic. The alley-cropping system with Atriplex nummularia proved efficient in the semi arid regions of Morocco (annual rainfall 200-350 mm). Barley was cropped (seeding rate $160 \mathrm{~kg} / \mathrm{ha}$ ) between atriplex (333 plants/ha) rows. Compared to farmers' monocropping system, dry matter consumable biomass yield of atriplex was significantly high in the alley-cropping system. The later system was more profitable than monocropping. Indeed, Laamari et al. (2005) determined the net benefit from atripex planting and barley-atriplex alley cropping over 15 years. The cumulative net benefit was 732.18 \$ /ha and 3342.53 \$/ha, respectively. The economic and agronomic assessment of alley-cropping shows that this technology is economically profitable.

(a4) Shrub mixing technique - Most fodder shrubs and trees are either low in essential nutrients (energy and/ or digestible nitrogen) or high in some secondary compounds (e.g. saponins, tannins, oxalates). These characteristics explain the low nutritive value of these fodder resources and the low performances of animals. For example, Acacia cyanophylla foliage is high in CT but low in digestible nitrogen. Atriplex spp. foliage is low in energy and true protein although they contain high levels of crude protein, fibre and oxalates (Ben Salem et al., 2010). Cactus cladodes are considered an energy source and high in water but they are low in nitrogen and fibre. Wealth information on the complementary nutritional role of these three shrub species and the benefits from shrub mixed diets for ruminants, mainly sheep and goats, is reported in the literature (Ben Salem et al., 2000, 2002, 2004, 2005b). This technique permits to balance the diet for nutrients and to dilute the adverse effects of secondary compounds and the excess of minerals, like salt. The association cactus-atriplex is a typical example of the benefits from shrub mixing. The high salinity and the low energy content of atriplex foliage could be overcome by cactus. In summary, diversification of shrub plantations should be encouraged to promote livestock production in the dry areas.

\section{Rangeland management}

Many semiarid and arid regions are characterised by an erratic nature of rainfall. The strong rainfall seasonality is among the main reasons of the high production variability of rangelands. These regions are facing other difficulties such as the high demographic pressure, edaphic constraints, and land tenure. The scope of range management is to ensure equilibrium between seasonal dietary requirements of animals and range production. To achieve this objective, we should operate on herds/flocks and/or on the rangelands. Animal reproduction could be manipulated to line up maximum feed requirements with the annual peak of range production. The low fodder potential of arid and semiarid areas coupled with degradation of natural rangelands resulted in excessive use of supplementary feeding within extensive system, which may have an important impact on the range, either positive or negative. The generalised utilisation of subsidised feed supplements resulted to an increase of stocking rates which were far beyond the carrying capacity, thus aggravating range degradation. Adjustment of the stocking rate, rotational and/or differed grazing could be emphasised to reach this objective. Manipulating vegetation consists in introducing other animal species

R. Bras. Zootec., v.39, p.337-347, 2010 (supl. especial) 
whose positive or negative impact may influence its evolution over time. Options for better management of private rangelands could be easily adopted by corresponding herders. However, the application of these options on collective rangelands is difficult. Communal systems, whereby range, land and water resources are public, invariably constitute an unfavourable circumstance for a rational management since animals are privately owned and their access to the resources cannot therefore be controlled, hence managed. The organisation of ethnic groups is à priori the tangible solution for better management of collective rangelands. A success story of this approach occurred in southern Tunisia (Tataouine area, annual rainfall 100-150 mm) where local communities were represented by agriculture development groups which are in charge of collective rangeland management and other activities. Collective rangelands extending over relative big areas hosted the rest technique for at least three consecutive years to rehabilitate degraded rangelands (plant cover rate and enhance biodiversity). Biomass production increased considerably and floristic composition was improved in protected rangelands.

\section{Better control of livestock watering}

Unlike feed nutrients, oftentimes water does not receive adequate consideration to ensure optimal nutrition and performance of ruminant animals, mainly those raised under drought conditions. Livestock may experience moderate to severe water restriction during a variety of commonly occurring environmental conditions (drought periods, in shipment, when grazing in areas far from watering sources, etc.). Indeed, water is required for digestion and metabolism of energy and nutrients, transport of nutrients and metabolites to and from cells in blood, excretion of waste products, heat balance, etc.

Water is essential for the adjustment of body temperature and for growth, reproduction and lactation mechanisms, for digestion pattern and for nutrients exchanges. Livestock requirements for water in dry areas are high due to high temperature and the radiation load from the sun. Another factor, at times more important than climatic conditions, is the type of vegetation being grazed. Much higher water intakes and water turnovers have been recorded for sheep grazing on halophytes than on grasslands (Ben Salem et al., 2010). The response of animals to water restriction (WR, i.e. decrease of water allowance in \% of ad libitum water intake) or water deprivation (WD, i.e. Water removal for a certain period) depends mainly on restriction rate, deprivation duration, animal species and breeds, physiological stage and diet composition. Water restriction less than $50 \%$ of ad lib water intake had no effect on DM intake, diet digestibility, urine excretion and rumen fermentation parameters in lambs (Hadjigeorgiou et al., 2000; Ben Salem \& Abidi, 2009). Milk yield and composition of ewes (Casamassima et al., 2008) and goats (Alamer, 2009) were not dramatically affected by $50 \%$ WR. Water deprivation for short periods is rather beneficial to range lambs and kids; it improves diet digestibility and $\mathrm{N}$ retention. Under WD conditions, the passage of ingesta through the digestive tract will slow down allowing more time for micro-organisms to digest available feed, greater salivary flow, which would improve rumen environmental conditions, and the concentration of protozoa in the rumen increases because of dehydration, leading to more efficient utilization of nutrients and the rate of fermentation increases. Overall, a WD for 3 days or more would have detrimental effects on feed intake by lambs (Wilson, 1970) and ewes which exhibited reduced milk production (Aganga et al., 1990).

Ruminants inhabiting arid areas have acquired various adaptation mechanisms that benefit them in enduring the water deficiency. They evolve higher water economy and utilize their body water more efficiently which would result in the maintenance of dry matter intake and production during the terms of water scarcity. Moussa \& Elkalifa (1992) noted that a five days water deprivation of desert goats had no effect on DM intake, but increased DM digestibility of the diet. The response to WR or WD is aggravated by feed restriction and the high level of salt in the diet. Water quality, which refers mainly to its temperature and minerals contents, could affect also livestock performances. These factors would affect water taste and odour, thus restrict water consumption and interfere with metabolic and digestive patterns in ruminants.

\section{Concluding Remarks}

Small ruminants are critical to the development of sustainable and environmentally sound production systems. The socioeconomic role of sheep and goats in communities living in arid and semiarid regions will be maintained over the forthcoming decades. Efforts should be intensified to improve productive and reproductive performances of these animals using simple and cost-effective options. Desertification, drought and global warming justify the needs for a serious reflection on the readjustment and or the establishment of new feeding strategies targeting the improvement of animal production without detrimental effects on the environment. Therefore, the development objectives should move towards resource conservation 
and natural resource management while striving for greater agricultural production. A wide range of local and alternative feed resources and secondary compound-containing plants and their extracts could, if adequately used, improve sheep and goat health, performances and the quality of their products. However, the wide transfer and adoption of these technical options at the farm level should be associated with the organisation of local institutions (farmers associations, NGOs, etc.), market organization and the support of policy makers to boost livestock production in arid and semiarid regions.

\section{References}

ABIDI, S.; BEN SALEM, H.; VASTA V., P.A. Spineless cactus (Opuntia ficus indica f. inermis) cladodes in the diet of lambs and kids: Digestion, growth and intramuscular fatty acid composition. Small Ruminant Research, v.87, p.9-16, 2009.

ABREU, A.; CARUlla, J.E.; LASCANO, C.E. et al. Effects of Sapindus saponaria fruits on ruminal fermentation and duodenal nitrogen flow on sheep fed a tropical grass diet with and without legume. Journal of Animal Science, v.82, p.1392-1400, 2004.

AGANGA, A.A.; UMUNNA, N.N.; OYEDIPE, E.O. et al. espone to water deprivation by Yankasa ewes under different physiological states. Small Ruminant Research, v.3, p.109$115,1990$.

AKKARI, H.; BEN SALEM, H.; GHARBI, M. et al. Feeding Acacia cyanophylla Lindl. foliage to Barbarine lambs with or without PEG: effect on the excretion of gastro-intestinal nematode eggs. Animal Feed Science Technology, v.147, p.182-192, 2008.

ALAMER, M. Effect of water restriction on lactation performance of Aardi goats under heat stress conditions. Small Ruminant Research, v.84, p.76-81, 2009.

ALARY, V.; NEFZAOUI, A.; BEN SALEM, H. et al. Impact assessment of the adoption of cactus pear cropping in livestockcereal systems in arid and semi-arid Tunisia. The case of Zoghmar, central Tunisia. Acta Horticulturae, v.728, p.279288, 2006.

ARAÙJO, L.M.; MEDEIROS, A.N.; NETO, A.P. et al. Protein enrichment of cactus pear (Opuntia ficus-indica Mill) using Saccharomyces cerevisiae in solid-state fermentation. Brazilian Archives of Biology and Technology, v.48, p.161168, 2005.

BEN SALEM, H.; NEFZAOUI, A.; BEN SALEM, L. et al. Deactivation of condensed tannins in Acacia cyanophylla Lindl. foliage by polyethylene glycol in feed blocks. Effect on feed intake, diet digestibility, nitrogen balance, microbial synthesis and growth by sheep. Livestock Production Science, v.64, p.51-60, 2000.

BEN SALEM, H.; NEFZAOUI, A.; BEN SALEM, L. Supplementing range goats in central Tunisia with feed blocks or a mixture of Opuntia ficus indica f. inermis and Atriplex nummularia L. Effects on behavioural activities and growth. In: INTERNATIONAL CONFERENCE ON GOATS, 7., 2000, Tours, France. Proceedings... Tours, 2000. p.988-989.

BEN SALEM, H.; NEFZAOUI, A.; BEN SALEM, L. Opuntia ficus indica f. inermis and Atriplex nummularia L. Two complementary fodder shrubs for sheep and goats. Acta Horticulturae, v.581, p.333-341, 2002.

BEN SALEM, H.; NEFZAOUI, A. Feed blocks as alternative supplements for sheep and goats. Small Ruminant Research, v.49, p.275-288, 2003.
BEN SALEM, H., NEFZAOUI, A., BEN SALEM, L. Spineless cactus (Opuntia ficus indica f. inermis) and oldman saltbush (Atriplex nummularia L.) as alternative supplements for growing Barbarine lambs given straw-based diets. Small Ruminant Research, v.51, p.65-73, 2004.

BEN SALEM, H.; ABDOULI, H.; NEFZAOUI, A. et al. Nutritive value, behaviour and growth of Barbarine lambs fed on oldan saltbush (Atriplex nummularia L.) and supplemented or not with barley grains or spineless cactus (Opuntia ficus indica $\mathrm{f}$. inermis) pads. Small Ruminant Research, v.59, p.229-238, 2005b.

BEN SALEM, H.; AL-JAWHARI, N.; DABA, M.A. et al. Feed block technology in West Asia and North Africa. Aleppo: ICARDA, 2005a. 111p.

BEN SALEM, H.; MAKKAR, H.P.S.; NEFZAOUI, A. et al. Benefit from the association of small amounts of tannin-rich shrub foliage Acacia cyanophylla Lindl. with soya bean meal given as supplements to Barbarine sheep fed on oaten hay. Animal Feed Science Technology, v.122, p.173-186, 2005b.

BEN SALEM, H.; ABIDI, S. Recent advances on the potential use of Opuntia spp. in livestock feeding. Acta Horticulturae, v.811, p.317-324, 2009.

BEN SALEM, H.; NEFZAOUI, A.; MAKKAR, H.P.S. Feed supplementation blocks for increased utilization of tanniniferous foliages by ruminants. In: MAKKAR, H.P.S.; SANCHEZ, M.; SPEEDY, A.W. (Eds.). Feed supplementation blocks. Rome: FAO Animal Production and Health, 2007. p.185-205. (paper 164).

BEN SALEM, H.; SMITH, T. Feeding strategies to increase small ruminant production in dry environments. Small Ruminant Research, v.77, p.174-194, 2008.

BEN SALEM, H.; ZNAIDI, I.-A. Partial replacement of concentrate with tomato pulp and olive cake-based feed blocks as supplements for lambs fed wheat straw. Animal Feed Science Technology, v.147, p.206-222, 2008.

BEN SALEM, H.; NORMAN, H.C.; NEFZAOUI, A. et al. Potential use of oldman saltbush (Atriplex nummularia Lindl.) in sheep and goat feeding. Small Ruminant Research, v.91, p.13-28, 2010.

CASAMASSIMA, D.; PIZZO, R.; PALAZZO, M. et al. Effect of water restriction on productive performance and blood parameters in comisana sheep reared under intensive condition. Small Ruminant Research, v.78, p.169-175, 2008.

ÇÜREK, M.; ÖZEN, N. Feed value of cactus and cactus silage. Turkish Journal of Veterinary and Animal Science, v.28, p.633-639, 2004.

FELKER, P.; INGLESE, P. Short-term and long-term research needs for Opuntia ficus-indica (L.) Mill. Utilization in arid areas. Journal of Professional Association for Cactus Development, p.131-151, 2003.

GONZALEZ, C.L. Potential of fertilization to improve nutritive value of prickly pear cactus (Opuntia lindheimerii Engelm.). Journal of Arid Environments, v.22, p.323-331, 1989.

HADJIGEORGIOU, I.; DARDAMANI, K.; GOULAS, C. et al. The effect of water availability on feed intake and digestion in sheep. Small Ruminant Research, v.37, p.147-150, 2000.

HOSTE, $\mathrm{H}$. Interactions between nutrition and gastrointestinal infections with parasitic nematodes in goats. Small Ruminant Research, v.60, p.141-151, 2005.

HOSTE, H.; JACKSON, F.; ATHANASIADOU, S. et al. The effects of tannin rich plants on parasitic nematodes in ruminants. Trends in Parasitology, v.22, p.253-261, 2006.

JOUANY, J.-P.; MORGAVI, D.P. Use of 'natural' products as alternatives to antibiotic fed additives in ruminant production. Animal v.1, n.10, p.1443-1466, 2007.

KAWAS, J.R.; ANDRADE-MONTEMAYOR, H.; LU, C.D. Strategic nutrient supplementation of free-ranging goats. Small Ruminant Research, v.89, p.234-243, 2010. 
LAAMARI, A.; BOUGHLALA, M.; CHRIYAA, A. Adoption and impact studies in Morocco. In: SHIDEED KAMIL, H.; EL MOURID, M. (Eds). Adoption and impact assessment of improved technologies in crop and livestock production systems in the WANA region. The development of integrated Crop/Livestock Production in Low Rainfall Areas of Mashreq and Maghreb Regions (Mashreq/Maghreb Project). Aleppo, Syria: ICARDA, 2005. p.107-118.

LENG, R.A.; BIRD, S.H.; KLIEVE, A. et al. The potential for tree forage supplements to manipulate rumen protozoa to enhance protein to energy ratios in ruminants fed on poor quality forages. In: SPEEDY, A.; PUGLIESE, P.-L. (Eds.) Legume trees and other fodder trees as protein sources for livestock. Rome: FAO Animal Production and Health, 1992. p.177-191. (Paper 102).

MAKKAR, H.P.S. Effects and fate of tannins in ruminant animals, adaptation to tannins, and strategies to overcome detrimental effects of feeding tannin-rich feeds. Small Ruminant Research, v.49, p.241-256, 2003.

MAKKAR, H.P.S. Feed supplementation block technology: Past, present and future. In: MAKKAR, H.P.S.; SANCHEZ, M.; SPEEDY, M. (Eds.) Feed supplementation blocks. Rome: FAO, 2007. 248p.

MAKKAR, H.P.S.; FRANCIS, G.; BECKER, K. Bioactivity of phytochemicals in some lesser-known plants and their effects and potential applications in livestock and aquaculture production systems. Animal, v.1, p.1371-1391, 2007.

MAKKAR, H.P.S.; BECKER, K. Beneficial effects of saponins on animal production. In: OLESZEK, W.; MARSTON, A. (Eds.) Saponins in food, feedstuffs and medicinal plants. Kluwer Academic Publishers, 2000. p.218-286.

MIN, B.R.; BARRY, T.N.; ATTWOOD, G.T. et al. The effect of condensed tannins on the nutrition and health of ruminants fed fresh temperate forages: a review. Animal Feed Science Technology, v.106, p.3-19, 2003.

MOUSA, H.M.; ELKALIFA, M.Y. Effect of water deprivation on dry matter intake, dry matter digestibility, and nitrogen retention in Sudan desert lambs and kids. Small Ruminant Research, v.6, p.311-316, 1992.

OLIVEIRA, M.A. Production of fungal protein by solid substrate fermentation of cactus Cereus peruvianus and Opuntia ficus indica. Quimica Nova, v.24, p.307-310, 2001.

RAMIREZ-RESTREPO, C.A.; BARRY, T.N.; POMROY, W.E. et al. Use of Lotus corniculatus containing condensed tannins to increase summer lamb growth under commercial dryland farming conditions with minimal anthelmintic drench input. Animal Feed Science Technology, v.122, p.197-217, 2005.

REKIK, M.; BEN SALEM, H.; LASSOUED, N. et al. Supplementation of Barbarine ewes with spineless cactus (Opuntia ficus-indica f. inermis) cladodes during late gestation-early suckling: Effects on mammary secretions, blood metabolites, lamb growth and postpartum ovarian activity. Small Ruminant Research, v.90, p.53-57, 2010.

SANTOSO, B.; KILMASKOSSU, A.; SAMBODO, P. Effects of saponin from Biophytum petersianum Klotzsch on ruminal fermentation, microbial protein synthesis and nitrogen utilisation in goats. Animal Feed Science Technology, v.137, p.58-68, 2007.

SANTOSO, B.; MWENYA, B.; SAR, CH. et al. Effect of Yucca schidigera with or without nisin on ruminal fermentation and microbial protein synthesis in sheep fed silage- and hay-based diets. Journal of Animal Science, v.75, p.525-531, 2004.

STINTZING, F.C.; CARLE, R. Cactus stems (Opuntia spp.): A review on their chemistry, technology, and uses. Molecular Food and Nutrition Research, v.49, p.15-194, 2005.

TEGEGNE, F.; KIJORA, C.; PETERS, K.J. Study on the effects of incorporating various levels of cactus pear (Opuntia ficusindica) on the performance of sheep. In: CONFERENCE ON INTERNATIONAL AGRICULTURAL RESEARCH FOR DEVELOPMENT, 2005, Stuttgart-Hohenheim. Proceedings... Stuttgart-Hohenheim: 2005. p.1-5.

VERAS, R.M.L.; FERREIRA, M.A.; CARVALHO, F.F.R. et al. Farelo de palma forrageira (Opuntia Picus-indica Mill) em substituiçao ao milho. 1. Digestibilidade aparente de nutrientes. Revista Brasileira de Zootecnia, v.31, p.13021306, 2002.

WAGHORN, G.C. Beneficial and detrimental effects of dietary condensed tannins for sustainable sheep and goat production. Progress and challenges. Animal Feed Science Technology, v.147, p.116-139, 2008.

WANG, C.J.; WANG, S.P.; ZHOU, H. Influences of flavomycin, ropadiar, and saponin on nutrient digestibility, rumen fermentation, and methane emission from sheep. Animal Feed Science Technology, v.148, p.157-166, 2009.

WILSON, A.D. Water economy and food intake of sheep when watered intermittently. Austalian Journal of Agricultural Research, v.21, p.273-281, 1970. 